\title{
5
}

\section{Bacteriophages in Dairy Industry: PCR Methods as Valuable Tools}

\author{
Beatriz del Río, María Cruz Martín, Víctor Ladero, Noelia Martínez, \\ Daniel M. Linares, María Fernández and Miguel A. Alvarez \\ Instituto de Productos Lácteos de Asturias, IPLA-CSIC, \\ Spain
}

\section{Introduction}

Microorganisms have been empirically used since ancestral times to produce fermented dairy products from milk. In the actual dairy industry, milk is subjected to large scale fermentation processes that involve microorganisms mostly belonging to the Lactic Acid Bacteria (LAB) group. Bacteriophages that infect LAB have been claimed as one of the principal sources of fermentation failure (spoilage or delay) on the manufacture of many dairy products (Brüssow et al., 1998; Josephsen \& Neve, 1998; Garneau \& Moineau, 2011). Some estimates assume that virulent phages are the primary direct responsible of the largest-economic loss of dairy factories, since they affect negatively up to the $10 \%$ of all milk fermentations (Moineau \& Levesque, 2005).

Starter cultures consisting in selected bacterial strains are added to the fermentation vats to enhance the fermentative process and also to improve or influence the flavor and texture of the cultured products. The starter culture population grows through the fermentation process and reaches high levels inside the industrial vat. This is the perfect environment where bacteriophages can infect sensitive bacteria. The lysis of the infected host-bacteria can decrease several folds the total number of starter cells with consequences ranging from the delay of the acidification with quality changes of the final product, to the total failure of the fermentation.

Even with frequent cleaning, disinfestations and sterilization of all the facilities, the total absence of phages in the dairy plants is a utopia. The number and types of phages that are introduced within the system, presumably as a consequence of the constant supply of wild phages, is very variable and different subpopulations can prevalence as soon as a susceptible strain is introduced in the fermentation scheme (Neve et al., 1995; Bruttin et al., 1997; Chibani-Chennoufi et al., 2004; Kleppen et al., 2011). In fact, bacteriophages have been detected in variable titer in the milk, appliances of the factory, additives and starter cultures.

Since dairy bacteriophages are one of the mayor dairy threats, great research efforts have been made to reduce its load on dairy plants and to design new monitoring methods for their early detection (Magadán et al., 2009; Garneau \& Moineau, 2011). Classical microbiological assays are routinely used on dairy plants to test the presence of bacteriophages. The spot/plaque assay and the turbidity/growth test are the two methods 
more frequently employed (Svensson \& Christiansson, 1991; Neve et al., 1995; Capra et al., 2006, 2009; Atamer et al., 2009). These microbiological assays are based on the inhibitory effect of the bacteriophages in the host strain growth. The culture activity is measured in such a way that the presence of a bacteriophage in the tested sample inhibits the growth of the host strain and also decreases the production of lactic acid.

Although the microbiological detection methods are economically accessible, they have undesirable features such us the long processing time, since they take at least 24 hours to be completed. In addition, bacteriophages are extremely host-specific, so one phage can only infect one or few strains of bacteria, forcing to maintain a big collection of LAB strains that can be tested. Furthermore, a negative result on the spot/plaque assay or the turbidity/growth test does not guarantee the sample is phage-free, but it could also indicate that the host strain chosen is not sensitive to the bacteriophage on the sample.

Due to all these disadvantages, classical microbiological methods have being ousted by more sensitive, faster, and accurate genetic tools as the polymerase chain reaction (PCR). This is a specific and sensitive technology used to detect and identify (traditional PCR), and also to quantify (quantitative PCR) minimal amounts of bacteriophage DNA from samples of different dairy sources. Therefore, the PCR is a fast and reliable approach to screen a great number of samples for phage DNA. In most cases, low quantities of the sample (milk, whey, yogurt, etc) can be directly checked for bacteriophage presence by PCR.

Since the traditional PCR generates DNA fragments of specific size, different protocols have been designed not only to detect but to identify, by fragment size discrimination, bacteriophages that infect the main dairy LAB species used in the dairy industry such as Lactobacillus casei/paracasei, Lactobacillus delbrueckii, Lactobacillus helveticus, Streptococcus thermophilus, and Lactococcus lactis (Labrie \& Moineau, 2000; Binetti et al., 2005; Quiberoni et al., 2006, 2010; Zago et al., 2006, 2008; del Río et al., 2007). One of the advantages of the PCRbased methods is that they can be applied in the raw milk received in the fermentation plant and within hours, each milk batch can be classified for its phage type content and it could be rapidly distributed. For example, if $L b$. delbrueckii phages are detected in the raw milk, the batch cannot be used for the elaboration of yoghurt but the milk could be redirected to elaborate cheese, buttermilk, bottled to drink milk or dried to skim milk, thus allowing for an efficient distribution of the raw material. PCR-based approaches have been also applied for routine checking of lysogenic strains in starter cultures, which contain hidden temperate bacteriophages that have the potential to become lytic and compromise the fermentation process (Martín et al., 2006).

A step forward is the use of the quantitative real-time PCR (qPCR), which allows the quantification of phage particles in the sample, is faster and more sensitive than the traditional PCR. Additionally, the use of different fluorochromes enables the identification of multiple bacteriophage species in the same reaction (del Río et al., 2008; Martín et al., 2008; Verreault et al., 2011).

The detection by PCR-based methods might be easily incorporated into dairy industry routines to monitor the presence of phages and be included as part of the prevention strategy for controlling phage contamination. This methodology allows the detection of bacteriophages directly in a small input volume of industrial samples. It also reduces the screening time, since the sample can be directly checked for bacteriophages, avoiding 
previous enrichment steps with the sensitive host, needed for most of the microbiological methods. The correct and rapid identification and quantification of bacteriophages potentially able to attack starter cultures allows for rapid decisions with regard to the destination of contaminated milk that can be used for elaboration processes in which the phages detected do not constitute a threat. The possibility to reduce the milk storage time plays an important strategic role with economic implications for the dairy industry.

\section{Traditional PCR}

The PCR (polymerase chain reaction) is a broadly used molecular biology technique developed in 1983 by Kary Mullis and collaborators (Saiki et al., 1985; Mullis \& Faloona, 1987), in which a single or a few copies of a specific DNA fragment present in a sample are amplified by a DNA polymerase in a thermal cycler to produce up to $2^{35}$ copies in few hours. At the end of the amplification reaction, the product is analyzed on an agarose gel and the DNA fragments are separated by size. To ensure the specificity of the reaction, both the target DNA sequence and the flanking primers are chosen in such a way that only samples containing the specific DNA are PCR-positives and yield DNA fragments of known size. Fig. 1 shows a graphic representation of the process to detect and identify bacteriophages that infect different LAB species from dairy samples by PCR amplification and subsequent size discrimination on agarose gel.

During the last fifteen years, the PCR-based methodology has been applied in several stages of dairy product manufacturing to rapid detect, identify and characterize different bacteriophages that infect LAB strains (e.g. S. thermophilus, Lactobacillus sp. and Lb. casei/paracasei). The technique has been adapted to detect phages in milk samples (Binetti et al., 2005; Dupont et al., 2005; del Río et al., 2007), in cheese whey (Brüssow et al., 1994; Labrie and Moineau, 2000), in the equipment within the factory (Verreault et al., 2011, Kleppen et al., 2011) or even from air samples (Verrault et al., 2011) with a detection limit of $10^{3}-10^{4}$ phage particles per milliliter.

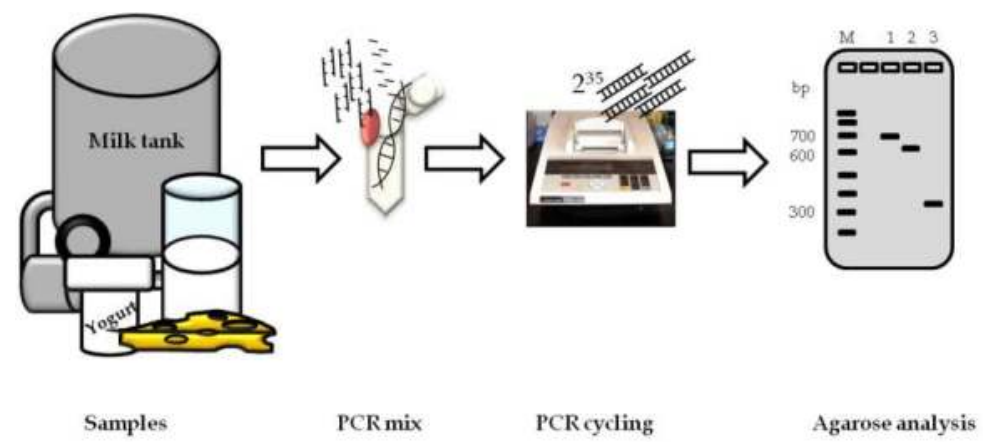

Fig. 1. Detection of bacteriophages in dairy samples by PCR. A variety of dairy samples can be checked for bacteriophage presence. The sample is loaded in a tube with the PCR mix and subjected to amplification in a thermocycler. At the end of the process, the amplified DNA is analyzed in an agarose gel and the bacteriophage is identified by the fragment size. Lane 1: S. thermophilus phage (750 bp), Lane 2: Lb. delbrueckii phage (650 bp), Lane 3: Lc. lactis phage (300 bp). 
S. thermophilus bacteriophages have been identified in industry milk fermentation samples as yogurt and cheese whey, after phage DNA extraction and subsequent PCR (Brüssow et al., 1994) or by direct PCR of milk (Binetti et al., 2005; Dupont et al., 2005, del Río et al., 2007). A PCR protocol to detect $L b$. casei/paracasei bacteriophages from milk and other commercial samples as fermented milk and cheese whey was also designed (Binetti et al., 2008). In addition, Lb. delbrueckii bacteriophages have been detected in milk and yogurt samples (del Río et al., 2007). Moreover, several protocols have been published to detect and identify the three species of Lc. lactis bacteriophages most frequently found in milk plants (c2, 936 and 335), in cheese whey samples (Labrie \& Moineau, 2000; Dupont et al., 2005; Deveau et al., 2006; Szczepańska et al., 2007; Suárez et al., 2008; Kleppen et al., 2011), milk (del Río et al., 2007) and even in the factory equipment (Verreault et al., 2011; Kleppen et al., 2011) or air samples (Verrault et al., 2011).

\subsection{Multiplex PCR}

The manufacture of a great number of cultured milk products implies the addition of starter cultures. The composition of modern dairy starter cultures is increasing on complexity and they are actually made of a variety of strains. This variety of strains raises the total number of different bacteriophage species that might affect the starter culture and therefore the quality of the final product. Usually, one PCR protocol is designed to specifically amplify and detect only one species of bacteriophage in a sample, so more than one PCR would be needed to detect all the phage types that could be present in a sample of a product manufactured with a complex starter culture.

An elegant and efficient solution for such a problem has been proposed by different authors who have developed multiplex PCR assays to check for more than one phage species in a single reaction. There are different multiplex assays towards multi-type bacteriophage detection in the literature (Labrie \& Moineau, 2000; Quiberoni et al., 2006; del Río et al., 2007). In 2000, Labrie and Moineau designed a multiplex PCR method to detect in a single reaction the presence of the three $L c$. lactis phages species considered as problematic in dairy companies, namely 936, c2, and P335. The assay was optimized for detection and identification of the three phage types from whey samples. Later on, del Río et al. (2007) extended the PCR for the detection of two additional phage groups: bacteriophages infecting $S$. thermophilus and $L b$. delbrueckii, starters of common use for the elaboration of yoghurt. This simple and rapid multiplex PCR method detects the presence of bacteriophages infecting LAB species most commonly used as starters in dairy fermentations: the three genetically distinct groups of Lc. lactis phages species (P335, 936 and c2) plus phages infecting $S$. thermophilus and Lb. delbrueckii.

\subsection{PCR-detection of lysogenic strains in starter cultures}

Phages are ubiquitous organisms, in the particular case of dairy fermentations, the main source of phages is the raw milk, from where they spread and contaminate the dairy facilities. Other external sources of phage contamination that must be considered are the starter strains that carry prophages into their genome. The analysis of bacterial genomes revealed that prophages are more widespread than previously thought (Canchaya et al., 2003; Mercanti et al., 2011). 
Numerous LAB belonging to different genera are lysogenic bacteria, meaning that carry one or several inducible prophages integrated into their genomes. Functional prophages has been identified in species usually used in dairy fermentations such as Lc. lactis subsp. lactis, Lc. lactis subsp. cremoris, S. thermophilus, Lb. delbrueckii, Lb. casei, Lactobacillus rhamnosus or Bifidobacterium longum (Chopin et al., 2001; Desiere et al., 2002; Proux et al., 2002; Ventura et al., 2006, 2007, 2009; Zago et al., 2007; Durmaz et al., 2008).

The lysogenic strains are introduced and maintained in fermentation vats for extended periods of time where they are subjected to the stressful fermentation conditions. This environment may induce prophages into lytic cycle and release the viral. The risk for prophage induction and its consequences on the final product quality must be carefully evaluated when developing industrial fermentation processes thorough the selection of suitable prophage-free strains as starters.

Ideally, bacterial strains should be tested in conditions that mimic industrial fermentation processes for the induction of putative prophages. In this context, PCR can be used as a tool for the rapid screening towards the identification of lysogenic strains in large culture collections (Martín et al., 2006). The potential lysogenic strains should be further tested for their capacity to release phage particles. In fact, PCR methods could, overcome frequent problems of prophage induction assays such as lack of detection of the bacteriophages released due to a low viral production, the high sensitivity of the screened strain to the induction agent or the lack of a suitable host strain for the phage.

The cells can be tested by a direct phage-specific PCR assay. If no amplification is obtained, the problem strains can be tagged as phage-free. However, if the strain gives positive PCR result, it can be further assayed for prophage induction by using a known induction agent as mitomycin C (MitC). The presence of viral particles in the cell-free supernatant can be evaluated again with the same phage-specific PCR assay. Only those strains able to liberate functional phage particles would result in a positive PCR amplification and consequently should be discarded as starter strains (Fig. 2).

$\mathbf{A}$

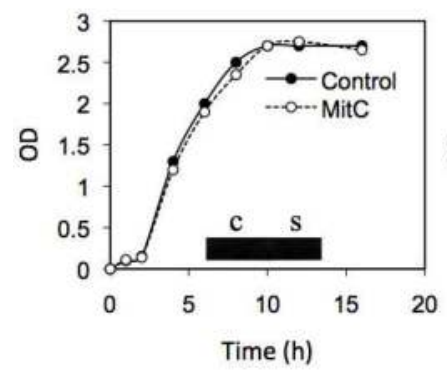

B

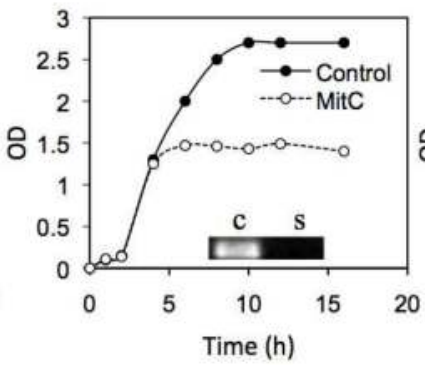

C

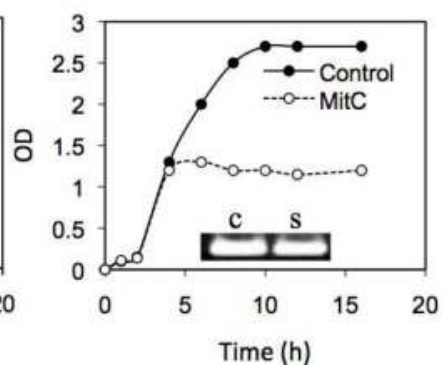

Fig. 2. PCR evaluation of putative lysogenic strain cultures induced with mitomycin $\mathrm{C}$ (MitC) (adapted from Martín et al., 2006). The optical density was measured in a control culture and in a culture induced with MitC after 4 hour. The Cells were PCR tested for the presence of prophages in the genome (c), and cleared supernatants of the induced cultures were also PCR tested (s). (A) Strain with no prophages. (B) Strain with no inducible prophages but inhibited by MitC. (C) Strain with inducible prophages. 
Those strains carrying not inducible prophages could be used as starters, although their use it is not recommended since they could constitute a pool of genes that can be transferred to incoming lytic phages by homologous recombination, thus expanding their host range (Bouchard \& Moineau, 2000; Durmaz \& Klaenhammer, 2000).

\subsection{Bacteriophages typification by PCR and amplicon sequencing}

The rotation of starter cultures that share similar technological properties but with a different pattern of phage susceptibility is the usual and most successful strategy to reduce the impact of phage attacks in dairy industries (Edmon \& Moineau, 2007; Kleppen et al., 2011). Therefore, the establishment of a system that allows not only to detect, but to classify the detected phages based on their host range would permit a rational modification of the strain rotation scheme.

In some detection methods, once a sample is confirmed for bacteriophage presence by PCR amplification, it is possible to get additional information from the amplicon nucleotide sequence. In this sense it has been described a PCR assay that correlates the host range of a bacteriophage and the nucleotide sequence of the amplified fragment (Binetti et al., 2005). This test is based on the amplification of the VR2 variable region of orf18, the antireceptor gene of $S$. thermophilus phages that was claimed as responsible for host specificity (Duplessis \& Moineau, 2001). The sequence of the VR2 variable sequence can be used to classify the detected phages within a host range and consequently to establish a rational rotation of the available starter cultures.

When a phage is detected by PCR the obtained sequence will classify it in a VR2 type (Binetti et al., 2005; Guglielmotti et al., 2009). This VR2 type would indicate those strains that are sensitive and those that are resistant to that phage in particular. The susceptible strains cannot be introduced in the elaboration routine and should be substituted for other similar strains that are not included in the same VR2 type thus being resistant to that particular phage. In other words, it is possible to know which strains are susceptible to be infected by the detected phages. This is a very useful tool for the dairy industry, since it allows preventing phage attack by designing a rational starter rotation system based on the phage types detected.

\section{Quantitative PCR}

Even though the PCR-based technology is a fast and sensitive approach to detect bacteriophages, traditional PCR has an important disadvantage since it is a qualitative but not a quantitative method for bacteriophage screening. In this sense it is important to note that $10^{5}$ phage particles per millilitre of milk has been estimated as the threat threshold (Neve \& Teuber, 1991; Emond \& Moineau, 2007; Magadán et al., 2009). Therefore, the mere presence of phage particles might be not enough to guaranty the useless of the material and quantitative approaches would avoid the disposal of milk that could still be useful.

The traditional PCR methodology is being changed towards a faster, more sensitive and useful technique, the quantitative PCR (qPCR). This is a new technology based on the traditional PCR that not only adds specificity, accuracy and speed to former PCR screening methods, but also allows the quantification of the number of copies of the target DNA, in this case bacteriophage particles in a dairy sample. Additionally, the qPCR collects the data in real time throughout the reaction and not just at the end point as the conventional PCR. This feature could be of great value for the dairy industry since it saves time and speed up the decision towards the use of the analyzed material, in case it is contaminated with bacteriophages. 
The qPCR technology monitors the increase of fluorescence emitted during the synthesis of the newly synthesized DNA fragment in each cycle. The reactions are characterized by the cycle in which the amplification of a target DNA results in a fluorescent signal that reaches the detection level of the equipment; this cycle is namely the threshold cycle (Ct) and it is directly proportional to the initial copies of target DNA in the sample (Logan et al., 2001). Absolute numbers are obtained by comparing the sample $\mathrm{Ct}$ value against a standard curve that is prepared with templates carrying a known titer of bacteriophages (Fig. 3).
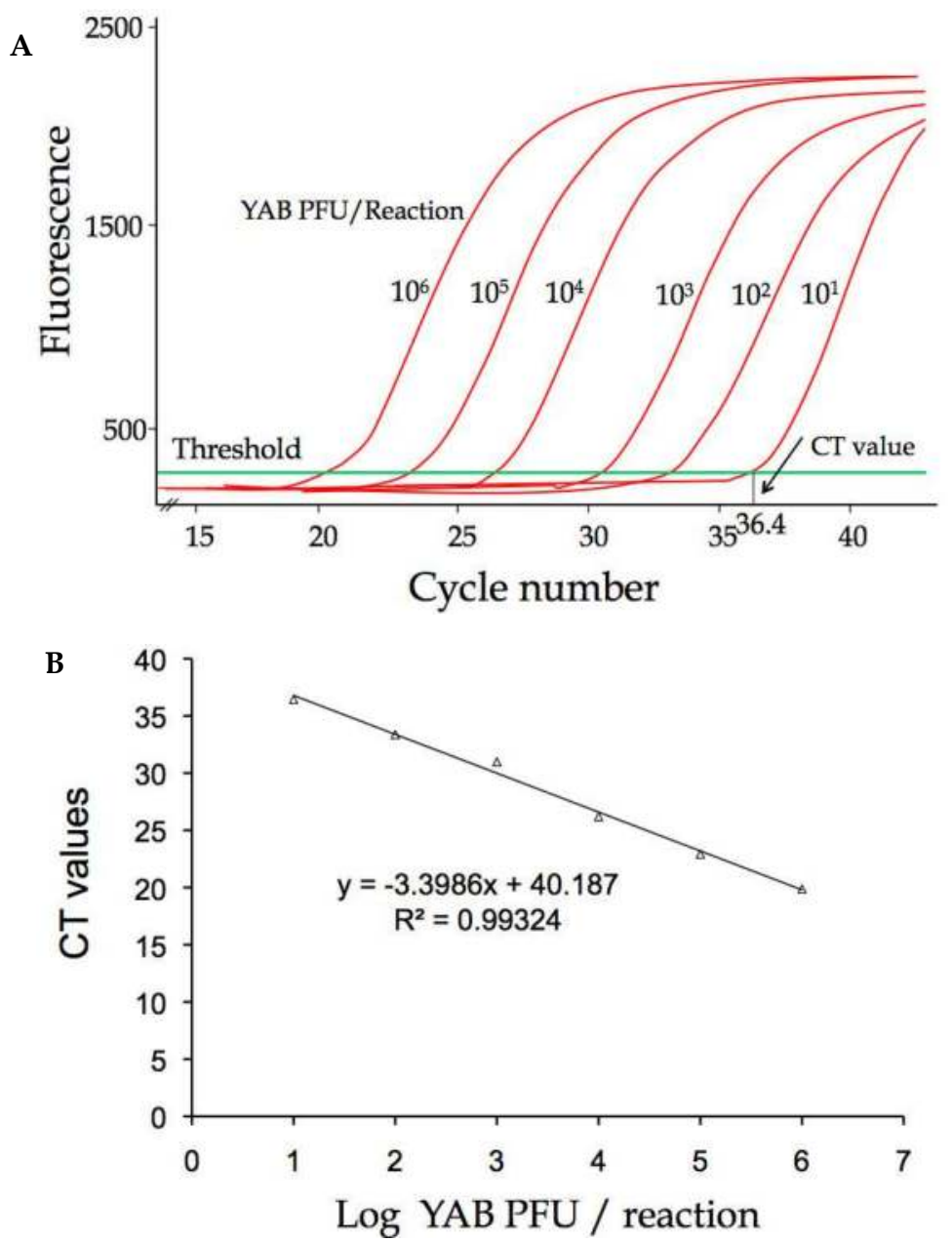

Fig. 3. qPCR analysis of 10-fold dilutions of milk artificially infected with a Lb. delbrueckii bacteriophage (YAB phage) (adapted from Martín et al., 2008). (A) Amplification plot of bacteriophage DNA in serial diluted samples starting at $10 \mathrm{PFU} /$ sample. (B) A linear correlation is established between the $\mathrm{C}_{\mathrm{T}}$ value and the logarithm of the number of phage particles on the sample. 
To detect the amplified DNA, non-specific fluorescent dyes that bind to any doublestranded DNA (e.g. SYBR ${ }^{\circledR}$ Green) or specific DNA probes (e.g. TaqMan ${ }^{\circledR}$ probes) could be used. The non-specific fluorescent dyes are flexible, inexpensive and accurate, but the formation of primers dimmers could led to detect false positives and the use of an internal positive control is not possible. Compare to DNA binding dyes, the fluorescence probe technology provides an additional level of specificity to the reaction, since in addition to the PCR primers a third oligonucleotide labeled with a fluorochrome (the probe) is added. Other significant advantage of using probe chemistry is that different probes can be labeled with different reporter dyes and be combined in a single reaction (multiplex qPCR). As each fluorescent signal is individually detected, the qPCR technology could be used as a qualitative tool to identify different bacteriophage species present in a sample. In addition, it allows the addition of an internal positive control to the PCR mix which is especially useful in dairy sample analysis, since in some food matrixes as milk many PCR inhibitors can be present and some screened samples could be annotated as false negatives (for a review see Martínez et al., 2011).

Several qPCR protocols based on DNA fluorescent probes have been described to detect, quantify and identify bacteriophages present in dairy samples. Martín et al. (2008) developed a qPCR method to quantify $L b$. delbrueckii bacteriophages present in milk samples. The assay combines two different TaqMan MGB probes, one which identify the phage and another for an internal positive control that is added to all the samples. The assay allows the quantification of $10^{2} \mathrm{Lb}$. delbrueckii bacteriophage particles per reaction and it could be also applied to test other dairy niches such as starter cultures and fermented milks.

As was described above, a multiplex qPCR assay has been applied to identify in a single reaction more than one different bacteriophage type. In this context, del Río et al. (2008) designed a multiplex assay to detect two types of $S$. thermophilus bacteriophages (cos and pac) in milk samples combining three probes individually labeled with different fluorochromes (one for each bacteriophage and another one for the internal control). The assay shown to be highly specific, since no false-positive or false-negative results were obtained even when the analyzed milk samples were artificially contaminated with $L b$. delbrueckii or Lc. lactis bacteriophages.

Concerning to Lc. lactis phages, Verreault et al. (2011) recently developed a qPCR method using the SYBR green fluorescence technology to quantify bacteriophages belonging to the 936 and c2 groups in aerosol and surface samples of a typical cheese manufacturing plant.

Even though the qPCR technology has shown to be a great platform to detect and quantify virulent phages in dairy plants, further advancements are needed in order to improve the automation of the process, the sensitivity of the detection in dairy samples susceptible of contain PCR inhibitors and to expand the possibility to target simultaneously a bigger number of different bacteriophages in a single reaction.

\section{Discussion/conclusions}

Bacteriophages that attack bacteria used as starters cause great economic losses to global dairy industry. Even though strict sanitation programs and rigorous culture handling are established on the dairy plants, the bacteriophage presence is ubiquitous in all the facilities in variable titer. PCR-based methods for early and fast detection and quantification of 
bacteriophage that might jeopardize the survival of the culture starters are shown to be effective and might be incorporated as routine control of bacteriophages in the dairy industry.

The machinery, surfaces and aerosols within the facilities of the dairy plant can be checked to ensure the absence or at least the low titer of bacteriophages that otherwise would be incorporated on the fermentative process. Surely, PCR can be applied to determine the potential uses of a batch of milk, but also could be applied to samples collected all through the fermentative process, starting with the raw milk and ending with the final product. Since PCR protocols are much faster than traditional microbiological methods, the raw milk can be checked for bacteriophages in an acceptable time, allowing decisions for the better use of contaminated material, which could be diverted toward procedures in which bacteriophages are deactivated or do not require a fermentative step with LAB starters. In consequence, whole tanks of raw milk are not kept for big periods of time and also the subsequent fermentative process is not on risk.

The presence of PCR inhibitors such calcium ions, plasmin, proteins, fat..., is a fact that should be taken into account in the design of PCR protocols to analyze dairy products. Special care must be taken when dairy samples are used directly as templates, because the presence of inhibitors may interfere with the PCR amplification and leads false negative results (Wilson, 1997; Ercolini et al., 2004). Magnetic capture hybridization (Dupont et al., 2005) or a previous DNA isolation from the sample, as is described for detecting pathogens in dairy samples (Cremonesi et al., 2007), are some of the additional steps that could be included in the PCR methods to remove PCR inhibitors and/or reduce the effect of the components of the dairy matrix.

Given that some qPCR-based protocols can confirm the bacteriophage presence in just 30 minutes, they are a great tool for fast detection of bacteriophage breakouts in a failed fermentative process and may help in the substitution of starter strain for another resistant to the detected phage. The qPCR methods save performing time compared to the traditional PCR, since the post-amplification processing is not generally needed. However, when the SYBR ${ }^{\circledR}$ Green is the qPCR technology of choice, a further processing of the amplicon (melting point or dissociation curve analysis) is essential in order to detect non-specific amplifications or primer-dimmers. The SYBR ${ }^{\circledR}$ Green chemistry could be the cheapest option for the screening of a large number of samples, but requires an extensive optimization of the protocols designed and also the complete analysis of the samples would take longer than the probe-based methods.

Both, traditional and real-time PCR techniques are extremely specific and their reliability depends on the design of the protocol to specifically target one bacteriophage species. However, a critical point and a potential limitation to design new specific PCR protocols, is the need of some prior information about the nucleotide sequence of the bacteriophage target gene. In this context, the new sequencing techniques are a valuable tool to characterize new bacteriophages isolated from the raw milk or within the facilities and hence, to increase the available phage genomic data. qPCR protocols should be updated with the new sequences as they become available.

The fact that a sample can be quickly assessed for bacteriophage presence by a qPCR assay do not necessary implies its classification as infective or non-infective for the starter cultures used in a particular dairy plant. The host range of bacteriophages is usually defined by 
traditional microbiological tests, using a collection of potential bacterial host. That process is cost- and time-inefficient for the dairy industry. Nevertheless, traditional PCR and amplicon sequencing have been successfully applied in dairy phages infecting $S$. thermophilus (Binetti et al., 2005) and Lc. lactis (Stuer-Lauridsen et al., 2003; Dupont et al., 2004), to correlate a specific nucleotide sequence with the host range of each phage. qPCR and PCR methods can be sequentially combined, applying first the qPCR method for a fast screening of a large batch of samples, followed by a traditional PCR in which the host range of the phage could be assessed and the potential host strains identified and discarded as starters for fermentative processes.

Continuous efforts are being made in order to improve the PCR-based protocols for the detection and quantification of bacteriophages from samples of any origin within the dairy plant. PCR-based methods could be included in the Hazard Analysis and Critical Control Points (HACCP) protocol to prevent phage accumulation niches and reduce their impact in dairy fermentations.

\section{Acknowledgments}

This work was performed with financial support from the Ministry of Science and Innovation, Spain (AGL2010- 18430). B. del Río and N. Martínez are beneficiary of a JAE DOC-CSIC contract (Spain). D. M. Linares is beneficiary of a FICYT contract (Asturias, Spain).

\section{References}

Atamer, Z.; Dietrichb, J.; Müller-Merbacha, M.; Neveb, H.; Hellerb, K.J. \& Hinrichsa, J. (2009). Screening for and characterization of Lactococcus lactis bacteriophages with high thermal resistance. International Dairy Journal, Vol.19, No.4, (April 2009), pp. 228-235, ISSN 0958-6946.

Binetti, A.G.; del Rio, B.; Martin, M.C. \& Alvarez, M.A. (2005). Detection and characterization of Streptococcus thermophilus phages based on the antireceptor gene sequence. Applied and Environmental Microbiology, Vol.71, No.10, (October 2005), pp. 6096-103, ISSN 0099-2240.

Binetti, A.G.; Capra, M.L.; Alvarez, M.A. \& Reinheimer, J.A. (2008). PCR method for detection and identification of Lactobacillus casei/paracasei bacteriophages in dairy products. International Journal of Food Microbiology, Vol.124, No.2, (May 2008), pp. 147-153, ISSN 0168-1605.

Bouchard, J.D. \& Moineau, S. (2000). Homologous recombination between a lactococcal bacteriophages and the chromosome of its host strain. Virology, Vol.270, No.1, (April 2000), pp. 65-75, ISSN 0042-6822.

Brüssow, H.; Freimont, M.; Bruttin, A.; Sidoti, J.; Constable, A. \& Fryder, V. (1994). Detection and classification of Streptococcus thermophilus bacteriophages isolated from industrial milk fermentation. Applied and Environmental Microbiology, Vol.60, No.12, (December 1994), pp. 4537-4543, ISSN 0099-2240.

Brüssow, H.; Bruttin, A.; Desiere, F.; Lucchini, S. \& Foley S. (1998). Molecular ecology and evolution of Streptococcus thermophilus bacteriophages--a review. Virus Genes. Vol.16, No.1, (January 1998), pp. 95-109, ISSN 0920-8569. 
Bruttin, A.; Desiere, F.; d'Amico, N.; Guérin, J.P.; Sidoti, J.; Huni, B.; Lucchini, S. \& Brüssow, H. (1997). Molecular ecology of Streptococcus thermophilus bacteriophage infections in a cheese factory. Applied and Environmental Microbiology, Vol.63, No.8, (August 1997), pp. 3144-3150, ISSN 0099-2240.

Canchaya, C.; Proux, C.; Fournous, G.; Bruttin, A. \& Brüssow, H. (2003). Prophage genomics. Microbiology and Molecular Biology Reviews, Vol.67, No.2, (June 2003), pp. 238-276, ISSN 1092-2172.

Capra, M.L.; Del, L.; Quiberoni, A.; Ackermann, H.W.; Moineau, S. \& Reinheimer, J.A. (2006). Characterization of a new virulent phage (MLC-A) of Lactobacillus paracasei. Journal of Dairy Science, Vol.89, No.7, (July 2006), pp. 2414-2423, ISSN 0022-0302.

Capra, M.L.; Binetti, A.G.; Mercanti, D.J.; Quiberoni, A. \& Reinheimer, J.A. (2009). Diversity among Lactobacillus paracasei phages isolated from a probiotic dairy product plant. Journal of Applied Microbiology, Vol.107, No.4, (October 2009), pp. 1350-1357, ISSN 1364-5072.

Chibani-Chennoufi, S.; Bruttin, A.; Dillmann, M.L. \& Brüssow, H. (2004). Phage-host interaction: an ecological perspective. Journal of Bacteriology. Vol.186, No.12, (June 2004), pp. 3677-3686, ISSN 0021-9193.

Chopin, A.; Bolotin, A.; Sorokin, A.; Ehrlich, S.D. \& Chopin, M. (2001). Analysis of six prophages in Lactococcus lactis IL1403: different genetic structure of temperate and virulent phage populations. Nucleic Acids Research, Vol.29, No.3, (February 2001), pp. 644-651, ISSN 0305-1048.

Cremonesi, P., Perez, G.; Pisoni, G.; Moroni, P.; (2007). Detection of enterotoxigenic Staphylococcus aureus isolates in raw milk cheese. Letters in Applied Microbiology, Vol.45, No.6, (December 2007), pp: 586-591, ISSN 0266-8254.

del Río, B.; Binetti, A.G.; Martín, M.C.; Fernández, M.; Magadán, A.H. \& Alvarez M.A. (2007). Multiplex PCR for the detection and identification of dairy bacteriophages in milk. Food Microbiology, Vol.24, No.1, (February 2007), pp. 75-81, ISSN 0740-0020.

del Río, B.; Martín, M. C.; Martínez, N.; Magadán, A.H. \& Alvarez, M.A. (2008). Multiplex fast real-time polymerase chain reaction for quantitative detection and identification of cos and pac Streptococcus thermophilus bacteriophages. Applied and Environmental Microbiology, Vol.74, No.15, (August 2008), pp. 4779-4781, ISSN 00992240.

Desiere, F.; Lucchini, S.; Canchaya, C.; Ventura, M. \& Brüssow, H. (2002). Comparative genomics of phages and prophages in lactic acid bacteria. Antonie Van Leeuwenhoek, Vol.82, No.1-4, (August 2002), pp. 73-91, ISSN 0003-6072.

Deveau, H.; Labrie, S.J.; Chopin, M.C. \& Moineau, S. (2006). Biodiversity and classification of lactococcal phages. Applied and Environmental Microbiology,Vol.72, No.6, (January 2006), pp. 4338-4346, ISNN 0099-2240.

Duplessis, M. \& Moineau, S. (2001). Identification of a genetic determinant responsible for host specificity in Streptococcus thermophilus bacteriophages. Molecular Microbiology, Vol.41, No.2, (July 2001), pp. 325-336, ISSN 0950-382X.

Dupont, K.; Vogensen, F.K.; Neve, H.; Bresciani, J. \& Josephsen, J. (2004). Identification of the receptor-binding protein in 936-species lactococcal bacteriophages. Applied and Environmental Microbiology, Vo.70, No.10, (October 2004), pp. 5818-5824, ISSN 00992240. 
Dupont, K.; Vogensen, F.K. \& Josephsen, J. (2005). Detection of lactococcal 936-species bacteriophages in whey by magnetic capture hybridization PCR targeting a variable region of receptor-binding protein genes. Journal of Applied Bacteriology, Vol.98, No.4, (April 2005), pp. 1001-1009, ISSN 0021-8847.

Durmaz, E. \& Klaenhammer, T.R. (2000). Genetic analysis of chromosomal regions of Lactococcus lactis acquired by recombinant lytic phages. Applied and Environmental Microbiology, Vol.66, No.3, (March 2000), pp. 895-903, ISSN 0099-2240.

Durmaz, E.; Miller, M.J.; Azcarate-Peril, M.A.; Toon, S.P. \& Klaenhammer, T.R. (2008). Genome sequence and characteristics of Lrm1, a prophage from industrial Lactobacillus rhamnosus strain M1. Applied and Environmental Microbiology, Vol.74, No.15, (August 2008), pp. 4601-4609, ISSN 0099-2240.

Emond, E. \& Moineau, S. (2007). Bacteriophages and food fermentations. In: Bacteriophage: Genetics and Molecular Biology, Mc Grath, S. \& van Sinderen, D. (Eds.), pp. 93-124, Caister Academic Press, ISBN 978-1-904455-14-1, Portland, USA.

Ercolini, D.; Blaiotta, G.; Fusco, V. \& Coppola, S. (2004). PCR-based detection of enterotoxigenic Staphylococcus aureus in the early stages of raw milk cheese making. Journal of Applied Microbiology, Vol.96, No.5 , (May 2004), pp. 1090-1098, ISSN 13645072.

Garneau, J.E. \& Moineau, S. (2011). Bacteriophages of lactic acid bacteria and their impact on milk fermentations. Microbial Cell Factories, 10 (Suppl 1):S20, (August 2011), Retrieved from <http://www.microbialcellfactories.com/content/10/S1/S20>, ISSN 1475-2859.

Guglielmotti, D.M.; Binetti A.G.; Reinheimer, J.A. \& Quiberoni, A. (2009). Streptococcus thermophilus phage monitoring in a cheese factory: Phage characteristics and starter sensitivity. International Dairy Journal, Vol.19, No.8, (August 2009), pp. 476-480, ISNN 0958-6946.

Josephsen, J. \& Neve, H. (1998). Bacteriophages and lactic acid bacteria. In: Lactic Acid Bacteria. Microbiology and Functional Aspects. Eds. Salminen, S., and S. von Wright, Marcel Dekker Inc, (February 1998), pp. 385-436, ISBN 082470133X, New York.

Kleppen, H.P.; Bang, T.; Nes, I.F. \& Holo, H. (2011). Bacteriophages in milk fermentations: Diversity fluctuations of normal and failed fermentations. International Dairy Journal, Vol.21, No.9, (September 2011), pp. 592-600, ISSN 0958-6946.

Labrie, S. \& Moineau, S. (2000). Multiplex PCR for detection and identification of lactococcal bacteriophages. Applied and Environmental Microbiology, Vol.66, No.3, (March 2000), pp. 987-994, ISSN 0099-2240.

Logan, J.M.; Edwards, K.J.; Saunders, N.A. \& Stanley, J. (2001). Rapid identification of Campylobacter spp. by melting peak analysis of biprobes in real-time PCR. Journal of Clinical Microbiology, Vol.39, No.6, (June 2001), pp. 2227-2232, ISSN 0095-1137.

Magadán, A.H.; Ladero, V.; Martínez, N.; del Río, B.; Martín M.C. \& Alvarez, M.A. (2009). Detection of bacteriophages in milk. In Handbook of Dairy Foods Analysis, L.M.L. Nollet \& F. Toldrá, (Eds.), pp. 469-482, CRC Press, Taylor \& Francis Group, ISBN 978-1-4200-4631-1, Boca Raton, USA.

Martín, M.C.; Ladero, V. \& Alvarez, M.A. (2006). PCR Identification of lysogenic Lactococcus lactis strains. Journal of Consumer Protection and Food Safety, Vol.1, No.2, (May 2006), pp. 121-124, ISSN 1661-5751. 
Martín, M.C.; del Río, B.; Martínez, N.; Magadán, A.H. \& Alvarez, M.A. (2008). Fast realtime polymerase chain reaction for quantitative detection of Lactobacillus delbrueckii bacteriophages in milk. Food Microbiology, Vol. 25, No.8, (December 2008); pp. 978982, ISSN 0740-0020.

Martínez, N.; Martín, M.C.; Herrero, A.; Fernández, M.; Alvarez, M.A. \& Ladero, V. (2011). QPCR as a powerful tool for microbial food spoilage quantification: Significance for food quality. Trends in Food Science and Technology, Vol.22, No.7, (July 2011), pp.367376, ISSN 0924-2244

Mercanti, D. J.; Carminati, D.; Reinheimer, J.A. \& Quiberoni, A. (2011). Widely distributed lysogeny in probiotic lactobacilli represents a potentially high risk for the fermentative dairy industry. International Journal of Food Microbiology, Vol.144, No.3, (January 2011), pp. 503-510, ISSN 0168-1605.

Moineau, S. \& Levesque, C. (2005). Control of bacteriophages in industrial fermentations. In: Bacteriophages: Biology and Applications, E. Kutter \& A. Sulakvelidze, (Eds.), pp. 285296, CRC Press, ISBN 0-8493-1336-8, Boca Raton, USA.

Mullis, K.B. \& Faloona, F.A. (1987). Specific synthesis of DNA in vitro via a polymerasecatalyzed chain reaction. Methods in Enzymology, Vol.155, (December 1987), pp. 335350, ISNN 0076-6879.

Neve, H. \& Teuber, M. (1991). Basic microbiology and molecular biology of bacteriophage of lactic acid bacteria in dairies. Bulletin of the IDF, Vol.263, (January 1991), pp. 3-15, ISSN 0250-5118.

Neve, H.; Berger, A. \& Heller, K.J. (1995). A method for detecting and enumerating airborne virulent bacteriophage of dairy starter cultures. Kieler Milchwirtschaftliche Forschungsberichte, Vol.47, No.3, (March, 1995), pp. 193-207, ISSN 0023-1347.

Proux, C.; van Sinderen, D.; Suárez, J.; García, P.; Ladero, V.; Fitzgerald, G.F.; Desiere, F. \& Brüssow, H. (2002). The dilemma of phage taxonomy illustrated by comparative genomics of Sfi21-like Siphoviridae in lactic acid bacteria. Journal of Bacteriology, Vol.184, No.21, (November 2002), pp. 6026-6036, ISSN 0021-9193.

Quiberoni, A.; Tremblay, D.; Ackermann, H.W.; Moineau, S. \& Reinheimer, J.A. (2006). Diversity of Streptococcus thermophilus phages in a large-production cheese factory in Argentina. Journal of Dairy Science, Vol.89, No.10, (October 2006), pp. 3791-3799, ISSN 0022-0302.

Quiberoni, A.; Moineau, S.; Rousseau, G.M.; Reinheimer, J. \& Ackermann, H.W. (2010). Streptococcus thermophilus bacteriophages. International Dairy Journal, Vol.20, No.10, (October 2010), pp. 657-664, ISSN 0958-6946.

Saiki, R.; Scharf, S.; Faloona, F.; Mullis, K.; Horn, G. \& Erlich, H. (1985). Enzymatic amplification of beta-globin genomic sequences and restriction site analysis for diagnosis of sickle cell anemia. Science, Vol.230 , No.4732, (December 1985), pp. 1350-1354, ISSN 0036-8075.

Stuer-Lauridsen, B.; Janzen, T.; Schnabl, J. \& Johansen, E. (2003). Identification of the host determinant of two prolate-headed phages infecting Lactococcus lactis. Virology, Vol.309, No.1, (April 2003), pp.10-17, ISSN 0042-6822.

Suárez, V.; Moineau, S.; Reinheimer, J.A. \& Quiberoni, A. (2008). Argentinean Lactococcus lactis bacteriophages: genetic characterization and adsorption studies. Journal of Applied Microbiology, Vol.104, No.2, (February 2008), pp. 371-379, ISSN 1364-5072. 
Svensson, V. \& Christiansson, A. (1991). Methods for phage monitoring. Bulletin FIL-IDF, Brussels, Belgium, Vol.263, pp. 29-39, ISSN 0250-5118.

Szczepańska, A.K.; Hejnowicz, M.S.; Kołakowski, P. \& Bardowski, J. (2007). Biodiversity of Lactococcus lactis bacteriophages in Polish dairy environment. Acta Biochimica Polonica, Vol. 54, No.1, (March 2007), pp. 151-158, ISSN 0001-527X.

Ventura, M.; Canchaya, C.; Bernini, V.; Altermann, E.; Barrangou, R.; McGrath, S.; Claesson, M. J.; Li, Y.; Leahy, S.; Walker, C.D.; Zink, R.; Neviani, E.; Steele, J.; Broadbent, J.; Klaenhammer, T.R.; Fitzgerald, G.F.; O'toole, P.W. \& van Sinderen, D. (2006). Comparative genomics and transcriptional analysis of prophages identified in the genomes of Lactobacillus gasseri, Lactobacillus salivarius, and Lactobacillus casei. Applied and Environmental Microbiology, Vol.72, No.5, (May 2006), pp. 3130-3146, ISSN 0099-2240.

Ventura, M.; Zomer, A.; Canchaya, C.; O'Connell-Motherway, M.; Kuipers, O.; Turroni, F.; Ribbera, A.; Foroni, E.; Buist, G.; Wegmann, U.; Shearman, C.; Gasson, M.J.; Fitzgerald, G.F.; Kok, J. \& van Sinderen, D. (2007). Comparative analyses of prophage-like elements present in two Lactococcus lactis strains. Applied and Environmental Microbiology, Vol.73, No.23, (December 2007), pp. 7771-7780, ISSN 0099-2240.

Ventura, M.; Turroni, F.; Lima-Mendez, G.; Foroni, E.; Zomer, A.; Duranti, S.; Giubellini, V.; Bottacini, F.; Horvath, P.; Barrangou, R.; Sela, D.A.; Mills, D.A. \& van Sinderen, D. (2009). Comparative analyses of prophage-like elements present in bifidobacterial genomes. Applied and Environmental Microbiology, Vol.75, No.21, (November 2009), pp. 6929-6936, ISSN 0099-2240.

Verreault, D.; Gendron, L.; Rousseau, G.M.; Veillette, M.; Massé, D.; Lindsley, W.G.; Moineau, S. \& Duchaine, C. (2011). Detection of airborne lactococcal bacteriophages in cheese manufacturing plants. Applied and Environmental Microbiology, Vol.77, No.2, (January 2011), pp. 491-497, ISSN 0099-2240.

Wilson, I.G. (1997). Inhibition and facilitation of nucleic acid amplification. Applied and Environmental Microbiology, Vol.63, No.10, (October 1997), pp. 3741-3751, ISSN 0099-2240.

Zago, M.; De Lorentiis, A.; Carminati, D.; Comaschi, L. \& Giraffa, G. (2006). Detection and identification of Lactobacillus delbrueckii subsp. lactis bacteriophages by PCR. Journal of Dairy Research, Vol. 73, No.2, (May 2006), pp. 146-153, ISSN 0022-0299.

Zago, M.; Suárez, V.; Reinheimer, J.A.; Carminati, D. \& Giraffa, G. (2007). Spread and variability of the integrase gene in Lactobacillus delbrueckii subsp. lactis strains and phages isolated from whey starter cultures. Journal of Applied Microbiology, Vol.102, No.2, (February 2007), pp. 344-351, ISSN 1364-5072.

Zago, M.; Rossetti, L.; Reinheimer, J.; Carminati, D. \& Giraffa, G. (2008). Detection and identification of Lactobacillus helveticus bacteriophages by PCR. Journal of Dairy Research, Vol.75, No.2, (May 2008), pp. 196-201, ISSN 0022-0299. 


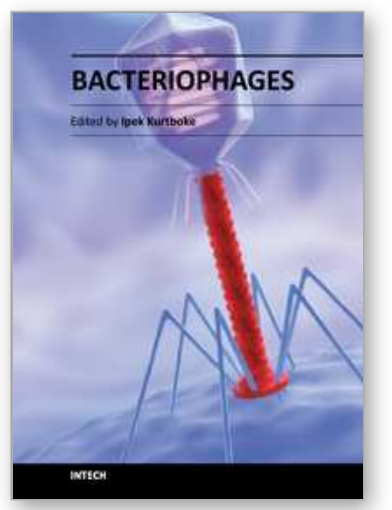

\author{
Bacteriophages \\ Edited by Dr. Ipek Kurtboke
}

ISBN 978-953-51-0272-4

Hard cover, 256 pages

Publisher InTech

Published online 14, March, 2012

Published in print edition March, 2012

Bacteriophages have received attention as biological control agents since their discovery and recently their value as tools has been further emphasized in many different fields of microbiology. Particularly, in drug design and development programs, phage and prophage genomics provide the field with new insights.

Bacteriophages reveals information on the organisms ranging from their biology to their applications in agriculture and medicine. Contributors address a variety of topics capturing information on advancing technologies in the field. The book starts with the biology and classification of bacteriophages with subsequent chapters addressing phage infections in industrial processes and their use as therapeutic or biocontrol agents. Microbiologists, biotechnologists, agricultural, biomedical and sanitary engineers will find Bacteriophages invaluable as a solid resource and reference book.

\title{
How to reference
}

In order to correctly reference this scholarly work, feel free to copy and paste the following:

Beatriz del Río, María Cruz Martín, Víctor Ladero, Noelia Martínez, Daniel M. Linares, María Fernández and Miguel A. Alvarez (2012). Bacteriophages in Dairy Industry: PCR Methods as Valuable Tools, Bacteriophages, Dr. Ipek Kurtboke (Ed.), ISBN: 978-953-51-0272-4, InTech, Available from: http://www.intechopen.com/books/bacteriophages/bacteriophages-as-a-problem-of-the-dairy-industry-pcrmethods-as-a-valuable-aid

\section{INTECH}

open science | open minds

\section{InTech Europe}

University Campus STeP Ri

Slavka Krautzeka 83/A

51000 Rijeka, Croatia

Phone: +385 (51) 770447

Fax: +385 (51) 686166

www.intechopen.com

\section{InTech China}

Unit 405, Office Block, Hotel Equatorial Shanghai No.65, Yan An Road (West), Shanghai, 200040, China 中国上海市延安西路65号上海国际贵都大饭店办公楼 405 单元 Phone: +86-21-62489820

Fax: $+86-21-62489821$ 
(C) 2012 The Author(s). Licensee IntechOpen. This is an open access article distributed under the terms of the Creative Commons Attribution 3.0 License, which permits unrestricted use, distribution, and reproduction in any medium, provided the original work is properly cited. 